\title{
Synthesis and Biological Evaluation of 1,3,8-Triazaspiro[4.5] decane-2,4-dione Derivatives as Myelostimulators
}

\author{
Valentina Yu (D), Assel Ten,, Lyailya Baktybayeva, ${ }^{2}$ Indira Sagatbekova, \\ Kaldybay Praliyev, ${ }^{1}$ Darya Zolotareva, ${ }^{3}$ Tulegen Seilkhanov, ${ }^{4}$ and Alexey Zazybin $\mathbb{D}^{3,5}$ \\ ${ }^{1}$ Institute of Chemical Sciences Named after A. B. Bekturov, Walikhanov Str., No. 106, Almaty 050010, Kazakhstan \\ ${ }^{2}$ Al-Farabi Kazakh National University, Al Farabi Av., No. 71, Almaty 050004, Kazakhstan \\ ${ }^{3}$ School of Chemical Engineering, Kazakh-British Technical University, 59 Tole-bi Str., Almaty 050000, Kazakhstan \\ ${ }^{4}$ Laboratory of Engineering Profile NMR Spectroscopy, Sh. Ualikhanov Kokshetau State University, Abay Str., No. 76, \\ Kokshetau 020000, Kazakhstan \\ ${ }^{5}$ School of Chemical \& Biochemical Engineering, Satbayev University, 22a Satpayev Str., Almaty 050013, Kazakhstan
}

Correspondence should be addressed to Valentina Yu; yu_vk@mail.ru

Received 2 November 2017; Revised 18 January 2018; Accepted 8 February 2018; Published 3 May 2018

Academic Editor: Artur M. S. Silva

Copyright (C) 2018 Valentina Yu et al. This is an open access article distributed under the Creative Commons Attribution License, which permits unrestricted use, distribution, and reproduction in any medium, provided the original work is properly cited.

\begin{abstract}
Spiroconnected $\mathrm{N}$-alkoxyalkylpiperidine hydantoins were obtained via the Strecker reaction of cyanohydrin with ammonium carbonate. 1,3,8-Triazaspiro[4.5]decane-2,4-diones have shown the myelostimulating activity in the artificially induced (with cyclophosphamide) myelodepressive syndrome. The compounds significantly accelerated the regeneration of lymphocyte and granulocyte cell pool of bone marrow hematopoiesis.
\end{abstract}

\section{Introduction}

Various groups of drugs of different origin and mechanism of action influence the process of hematopoiesis. Appreciable stimulatory effect on erythropoiesis has hormonal, ironcontaining drugs, vitamin supplements, and other drugs.

Very limited range of drugs that successfully stimulate leukopoiesis is known. Abnormal leukopoiesis accompanied by a decrease of the number of white blood cells may be due to harmful influence to bone marrow of the large doses of toxic substances and drugs (benzene, arsenic, chloramphenicol, phenylbutazone, diacarb, isoniazid, sulfanilamides, anticancer agents, pyrazolone derivatives, phenothiazines, etc.), different kind of irradiation, and so on. At mild leukopenia pyrimidine derivatives like methyluracil (methacin) and pentoxylum, which convert in the body to methyluracil, are administered $[1,2]$. Both drugs stimulate the synthesis of nucleic acids, proteins, cell division, leukopoiesis, and tissue regeneration and are administered to patients with burns, fractures, and long-term healing wounds as well as to those who in need to increase specific and nonspecific immune resistance of the organism. However, these drugs cannot be assigned during the infection, since they can be disposed by microorganisms and contribute to their reproduction and the further progress of an infectious disease. A leucogen-2-(2-ethoxy-2-oxo-1phenylethyl)-1,3-thiazolidine-4-carboxylic acid-stimulates leukopoiesis when it is significantly impaired and when agranulocytosis is arisen due to various reasons. Leucogen is contraindicated in patients with Hodgkin lymphoma and leukemia.

Sodium nucleinate induces leukocyte reaction and stimulates bone marrow activity. It possesses an activity of polyclonal immunostimulant which regulates migration of T-lymphocytes and cooperative processes of T- and B-lymphocytes; moreover it stimulates the phagocytic activity of macrophages and the production of nonspecific protection factors of the organism, especially during immunodeficiency; but it can cause uncontrolled cell division. Granocyte (lenograstim) recombined human granulocyte colony-stimulating 
factor involved in the production of granulocytes, macrophages, and megakaryocytes. It can also cause uncontrolled division of leukocytes with a suppression of the other ways of hematopoiesis. Leucomax (molgramostim) is a recombinant granulocyte macrophage colony-stimulating factor which increases colony formation and granulocytes, monocytes, and macrophages proliferation and stimulates phagocytic and cytotoxic function of mature granulocytes against bacteria and cancer cells. It is applied in various neutropenia, aplastic anemia, bone marrow transplantation, and leukopenia associated with infection (AIDS). Leucomax causes dysfunction of the gastrointestinal tract, cramps, myalgia, and headache. There also may be dysfunction of the cardiovascular system, hypotension, and cardiac arrhythmia.

Therefore, the search for new effective and safe leukopoiesis stimulants is of great importance.

The basis of this work is the idea of a synthetic "assembly" of fragments bearing potential bioactivity in a complex polyheterocyclic system to enhance the immune response in experimental animals with the artificially induced myelodepressive syndrome.

The reasons for this research are as follows: pronounced biological activity of $\mathrm{N}$-alkoxyalkylpiperidine derivatives [35], including leukopoiesis stimulation [6], and simplicity of synthesis of spirocyclic compounds [7], including hydantoin derivatives, among which the drugs are capable of treating arthritis with immunocorrection activity [8].

Hydantoins were mainly considered as anticonvulsant agents [9]. Among the known hydantoin derivatives are 5-ethyl-5-phenylhydantoin, 5,5-diphenylhydantoin, and its sodium salt (phenytoin), which are used in the treatment of chorea and epilepsy and as cardiac antiarrhythmics because of their regulatory action on bioelectric activity of the nervous system. Also some hydantoin derivatives, like barbiturates, have a soporific effect [10]. Some of the hydantoin derivatives possess anticancer and other types of activities [11-13].

\section{Material and Methods}

2.1. General. The chemicals used in this research are by Sigma Aldrich. IR spectra were recorded on Nicolet «5700 FT-IR» spectrometer in a thin film. ${ }^{13} \mathrm{C}$ and ${ }^{1} \mathrm{H}$ NMR spectra of synthesized compounds were recorded at Varian's «Mercury300 » spectrometer using $\mathrm{CDCl}_{3}$ as a solvent. The shooting temperature is $25^{\circ} \mathrm{C}$, unless otherwise specified. Control over the process of reactions and individuality of compounds was carried out by TLC on $\mathrm{Al}_{2} \mathrm{O}_{3}$ with iodine vapors development. Separation and purification of the substances were carried out by crystallization.

2.2. Peripheral Blood Hemogram Studies. For the studies of peripheral blood hemogram 48 adult albino laboratory rats of both sexes were used, 10-15 weeks of age and 210-280 g weight. Investigations were carried out in accordance with the "rules for the preclinical (nonclinical) studies of biologically active substances" and "ethical principles and guidelines for scientific experiments on animals" $[14,15]$. All the animals were kept under uniform conditions (wood litter of sawdust, the room temperature $22-24^{\circ} \mathrm{C}$, and the natural lighting mode); they were fed standard feed rations. Animals were divided into 8 groups of 6 animals. The 8 th group of animals was intact. All other experimental groups of animals were given cyclophosphamide [16] in a triple intramuscular injection at a dose of $30 \mathrm{mg} / \mathrm{kg}$ in a saline on average $0.6 \mathrm{~mL}$ of $1 \%$ solution. At 6 th, 7 th, and 8 th day of the experiment the animals of 1st-7th experimental group were injected intramuscularly with 1st, 2nd, 3rd, 4th, and 5th groups, an average of $0.1 \mathrm{~mL}$ of $1 \%$ solution ( $5 \mathrm{mg} / \mathrm{kg}$, saline), $\mathbf{1 1}, \mathbf{3}, \mathbf{1 0}, \mathbf{9}$, and 8, respectively, $6 \mathrm{th}, 0.1 \mathrm{~mL}$ of saline solution (placebo), and $7 \mathrm{th}$, an average of $0.1 \mathrm{~mL}(5 \mathrm{mg} / \mathrm{kg})$ of $1 \%$ solution of methyluracil $[1,2]$ (the drug for comparison). Blood sampling was performed at 09.00 am from the orbital vein of rats in sterile hematologic tubes VF-052SDK with $2 \mathrm{~mL}$ of EDTA (K2) on 12th, 19th, 33rd, and 40th days of the experiment $(1,7,21$, and 28 days after injection of 3, 8-11) under the mild anesthesia with ether. Blood tests were carried out on a hematology analyzer for animal blood «Abacus junior VET» (Diatron, Denmark). For the dual cytological control smears of blood were made to count blood leukogram. Blood smears were undergone Giemsa stain method [17] and counted under a microscope SA3300S immersion (magnification 7 . 100) 100 cells per each smear sample, then the relative amount of each type of the cells was converted into the absolute value [18].

Bone marrow examination was performed on 448 white mature albino laboratory mice of both sexes, 21-26 g weight. All animals were divided into 7 groups of 64 animals each. The 7th group of animals was intact. All the other experimental groups of animals were given cyclophosphamide in a single intramuscular injection at a dose of $160 \mathrm{mg} / \mathrm{kg}$ in saline, with an average of $0.3 \mathrm{~mL}$ of $1 \%$ solution. At $3 \mathrm{rd}, 4 \mathrm{th}$, and 5th days of the experiment the animals of the 1st-3rd experimental group were injected intramuscularly with an average of $0.1 \mathrm{~mL}$ of $10 \%$ solution ( $5 \mathrm{mg} / \mathrm{kg}$, saline), 11, 3, and 9, respectively, the animals of the 4 th group were injected with $0.1 \mathrm{~mL}(5 \mathrm{mg} / \mathrm{kg})$ of $10 \%$ solution of methyluracil, no bioactive compound was administered in the animals of the 5 th group, and the animals of the 6th group were injected with $0.1 \mathrm{~mL}$ of saline solution (placebo). The animal's euthanasia was performed by cervical dislocation of the spinal cord in the neck at 2nd, 4th, 6th, 8th, 10th, 14th, 21st, and 28th days of observation. Bone marrow from the femoral bones was used to prepare smears and quantification of karyocytes (nucleated cells per one femoral bone). Bone marrow smears were stained with Giemsa method, a myelogram was counted using SA3300S microscope and digital microphotography by immersion (magnification 7 • 100), 500 cells on each smear, and then the relative amount of each type of bone marrow cells was converted into absolute values per one femoral bone. Statistical analysis was performed using Student's test.

\section{Results and Discussion}

3.1. Synthesis and Characterization of Spiroconnected Hydantoins. For the synthesis of spiroconnected bicyclic compounds bearing two pharmacophores, hydantoin and $\mathrm{N}$ alkoxyalkylpiperidine, the Strecker reaction was chosen [19]. 

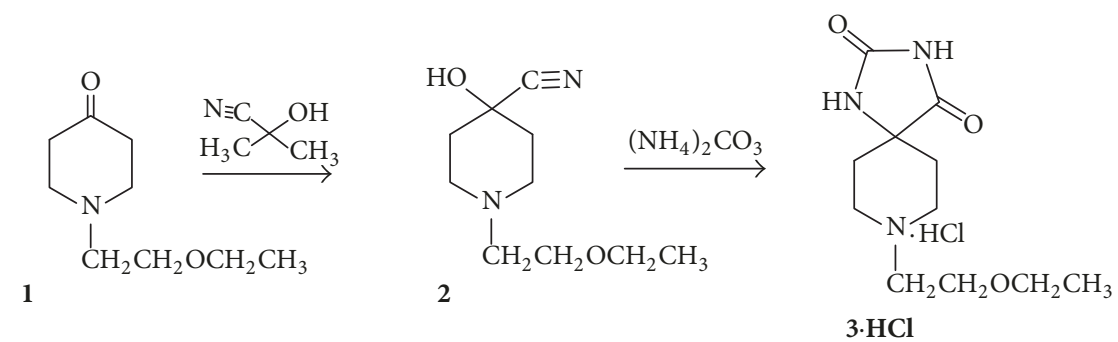

Scheme 1: Synthesis of spiroconnected bicyclic hydantoins with $\mathrm{N}$-alkoxyalkylpiperidine functionality using Strecker reaction.

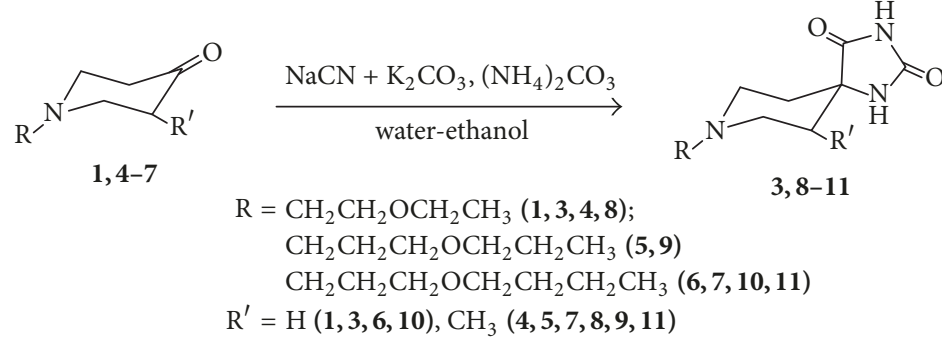

Scheme 2: Synthesis of spiroconnected bicyclic hydantoins with $\mathrm{N}$-alkoxyalkylpiperidine functionality using Bucherer-Bergs reaction.

TABLE 1: The proportions of reagents used in the synthesis of 8(2-ethoxyethyl-,3-ethoxypropyl-,3-butoxypropyl-)-6-(H, methyl)1,3,8-triazaspiro[4.5]decane-2,4-diones.

\begin{tabular}{lccc}
\hline Compound & \multicolumn{3}{c}{ Reagent amount, mol } \\
& 4-Piperidone & $\left(\mathrm{NH}_{4}\right)_{2} \mathrm{CO}_{3}$ & $\mathrm{NaCN}$ \\
\hline $\mathbf{3}$ & 0.040 & 0.082 & 0.053 \\
$\mathbf{8}$ & 0.038 & 0.076 & 0.046 \\
$\mathbf{9}$ & 0.025 & 0.190 & 0.050 \\
$\mathbf{1 0}$ & 0.033 & 0.066 & 0.043 \\
$\mathbf{1 1}$ & 0.048 & 0.190 & 0.096 \\
\hline
\end{tabular}

The interaction of cyanohydrin of 1-(2-ethoxyethyl)-4oxopiperidine 2 , obtained with $67.5 \%$ yield from 1 , with ammonium carbonate gives the compound $\mathbf{3} \cdot \mathbf{H C l}$ with $24 \%$ yield (Scheme 1).

Considering the high pharmacological potential of piperidine-hydantoin derivatives, we further applied Bucherer-Bergs reaction [20] for the synthesis of piperidinehydantoins (Scheme 2), allowing us to obtain the desired product in one step. The one-step reaction of obtained in $[21,22]$ 1-(2-ethoxyethyl)- (1), 1-(2-ethoxyethyl)-3-methyl(4), 1-(3-ethoxy-propyl)-3-methyl- (5), 1-(3-butoxypropyl)(6), and 1-(3-butoxypropyl)-3-methyl- (7) 4-piperidone with sodium cyanide and ammonium carbonate in an aqueousalcoholic solution was carried out in sealed vials with further neutralizing with diluted hydrochloric acid and evaporation of water to get a mixture of the reaction product with sodium chloride. The proportions of reagents used in the synthesis of 3, 8-11 are shown in Table 1.
The purification of the resulting novel products $\mathbf{3}, \mathbf{8}-\mathbf{1 1}$ was performed using column chromatography on alumina eluting with a mixture of benzene and ethanol at different ratios. The yields of 3-methyl- derivatives 8,11 were 1.5 higher than their $3 \mathrm{H}$-analogues $\mathbf{3}, \mathbf{1 0}$.

The IR spectra of the synthesized bicyclic compounds 3 and 8-11 contain doublet absorption band at $1700-1743 \mathrm{~cm}^{-1}$, corresponding to the two stretching vibrations of $\mathrm{C}=\mathrm{O}$ bonds. $\mathrm{N}-\mathrm{H}$ bond absorbs at $3329-3333 \mathrm{~cm}^{-1}$ and ether (COC) connection at $1115-1120 \mathrm{~cm}^{-1}$.

The ${ }^{13} \mathrm{C}$ NMR spectra of $\mathbf{3}$ and $\mathbf{8}-\mathbf{1 1}$ contain most lowfield singlet signals with chemical shift values $175.5-183.2 \mathrm{ppm}$ and $156.5-162.3 \mathrm{ppm}$ assigned to the carbon atoms of the hydantoin cycle; carbon signals of the piperidine ring of 3 and 10 correspond to triplets at 48.9 and $56.0 \mathrm{ppm}$ (C-7, C9); 30.1 and $36.1 \mathrm{ppm}$ (C-6, C-10). Singlets at 65.7-68.6 ppm were assigned to nodal carbon atom (C-5) of spirobicyclic compounds 3 and $\mathbf{8 - 1 1}$. The carbon $6-\mathrm{CH}_{3}$ of $\mathbf{8}, \mathbf{9}$, and 11 resonates at $12.6-12.9 \mathrm{ppm}$ (quartet). Doublet signal of spirobicyclic compounds 8, 9, and $\mathbf{1 1}$ at $12.6-12.9 \mathrm{ppm}$ is related to C-6; C-10 gives a triplet at 30.7-34.0 ppm.

In the case of 3-methylpiperidine-4-ones $4,5,7$ only one stereoisomer was obtained based on the fact that ${ }^{13} \mathrm{C} \mathrm{NMR}$ spectroscopy data is attributed to the configuration of the equatorial methyl group at C-6 $(1 / 2 W=6 \mathrm{~Hz})$ and axially oriented bond $(\mathrm{C}-5),(\mathrm{C}=\mathrm{O})(1 / 2 W=12-14 \mathrm{~Hz})$ [20]. This stereochemical result of the Bucherer-Bergs reaction which includes a series of sequential chemical steps is due to the high stereodirecting nucleophilic attack of the first CN-particle on the carbonyl group of piperidine-4-one, thereby forming a 4a-cyano-4e-hydroxypiperidine [23] with the retaining of the equatorial orientation of $3-\mathrm{CH}_{3}$ group. This is followed by the 


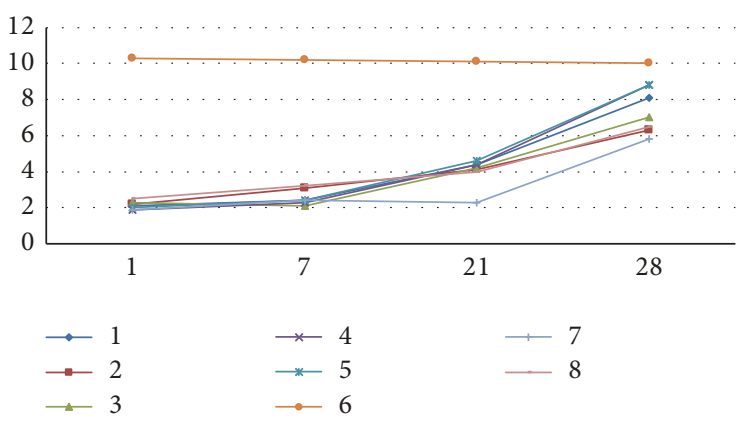

(a)

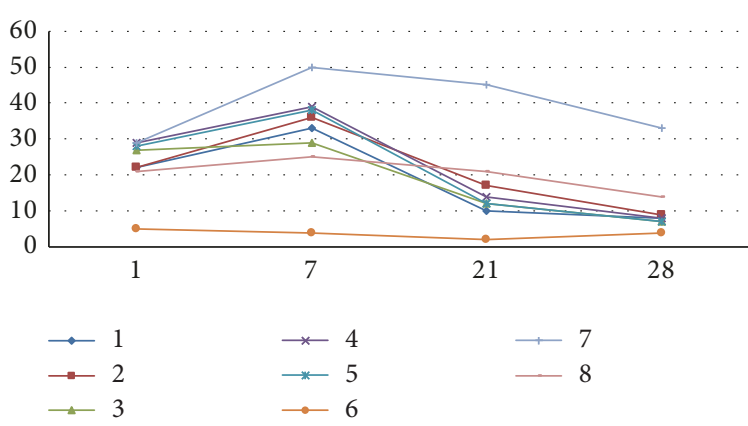

(c)

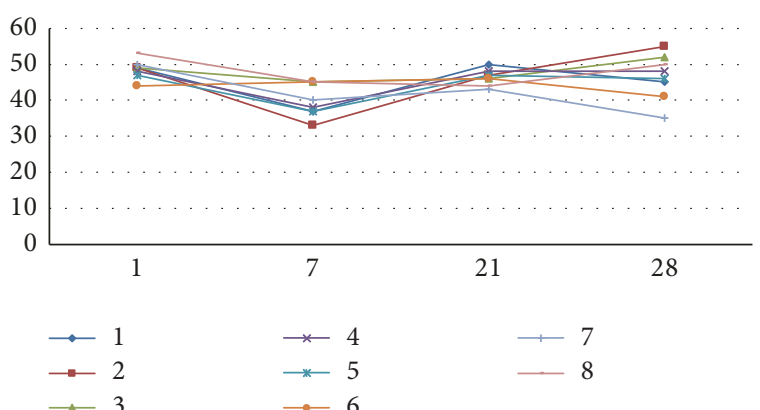

(b)

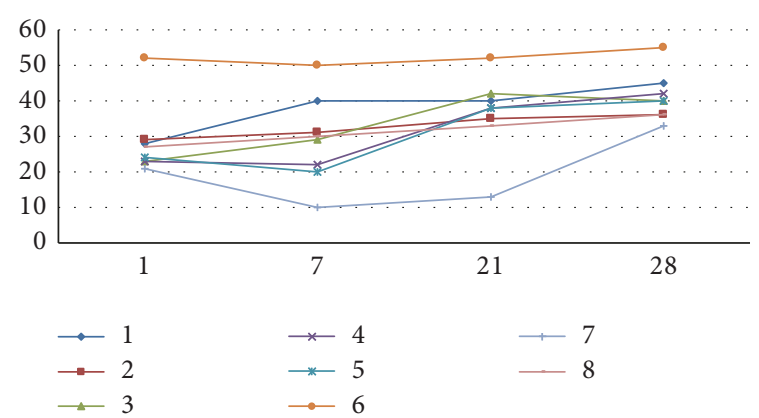

(d)

FIGURE 1: The hemogram of peripheral blood: white blood cells count (a), granulocytic cells (b), eosinophilic and monocytic cells (c), and lymphocytes (d) administration of $\mathbf{1 0}$ after the injection of cyclophosphamide solution (1), administration of $\mathbf{7}$ after the injection of cyclophosphamide solution (2), administration of $\mathbf{6}$ after the injection of cyclophosphamide solution (3), administration of $\mathbf{8}$ after the injection of cyclophosphamide solution (4), administration of 9 after the injection of cyclophosphamide solution (5), intact animals (6), control group (administration of placebo (saline) after the injection of cyclophosphamide solution) (7), and administration of methyluracil after the injection of cyclophosphamide solution (8). Time in days (the abscissa axis) versus number of cells (the axes of ordinates) ((a) $10^{9} / \mathrm{L}$; (b), (c), and (d) \%).

replacement of the hydroxyl to amino group without altering the configuration of the C-5 center.

3.2. Myelostimulating Activity Investigation. Values obtained for the intact control animals are presented in Supplementary Materials (Table S1) (Figure 1(a)).

The administration of cyclophosphamide resulted in the immunodepression syndrome with a left shift in the blood leukogram.

To assess the myelostimulating activity of bicycles $\mathbf{3}$, 8-11 hemogram the analysis of blood on the 7th, 21st, and 28 th day of observation was performed. The recovery of red blood cells and platelets was moderate for the groups 1 st-5th that undergo the injection of 3, 8-11. On the 28th day of observation the red blood cell count was in the range of $(3.54 \div 4.08) \cdot 10^{12} / \mathrm{L}$ in blood, with an increasing of hemoglobin level in blood from $(68.0 \pm 13.04) \mathrm{g} / \mathrm{L}$ to $(80.4 \pm 12.72) \mathrm{g} / \mathrm{L}$ that was not significantly different from the control. Somewhat lower values were detected in the 4 th group where compound 9 was administrated. The platelet count and platelet level in groups 1-3 and 5 where compounds 10, 11, 3, and 8, respectively, were administrated, showed insignificant difference (within experimental error) from the control. Thus the platelet count for the experimental groups was in the range from $(318.7 \pm 21.9) \cdot 10^{9} / \mathrm{L}$ to $(337.9 \pm 26.4)$ $\cdot 10^{9} / \mathrm{L}$ whereas in the control group it was $(336.98 \pm 43.8) \cdot$
$10^{9} / \mathrm{L}$. The platelet level in the experimental groups was on average $(0.48 \pm 0.01) \%$ while in the control it was $(0.35 \pm$ 0.02)\%.

After injection of the compounds $\mathbf{3}$ and 8-11 the significant changes were registered in the white blood cell count and blood leukogram at the 21st and 28th day of observation. The white blood cells count in peripheral blood after 28 days of observation recovered in the dynamics: a leukocyte range corresponding to the first day of administration of bioactive compounds $(1.9 \div 2.44) \cdot 10^{9} / \mathrm{L}$ increased to $(2.2 \div 3.2) \cdot 10^{9} / \mathrm{L}$ to the 7 th day of observation and $2.2-2.5$ times to the 21 st day of observation reaching $(4.1 \div 4.7) \cdot 10^{9} / \mathrm{L}$. On the 28 th day of observation it reached in some groups the level of intact animals (from $(6.2 \pm 0.9) \cdot 10^{9} / \mathrm{L}$ to $(8.7 \pm 1.6) \cdot 10^{9} / \mathrm{L}$ ); that is, it increased towards the values of 1st day of observation in 2.7 and 4.6 times $(p \leq 0.05)$, respectively (Figure 1(a)). On the 28th day of observation the white blood cells count in the groups where $10(8.2 \pm 1.1) \cdot 10^{9} / \mathrm{L}$ and $8(8.7 \pm 1.6) \cdot$ $10^{9} / \mathrm{L}$ were administrated, and the value of the control group (placebo) $(5.5 \pm 0.9) \cdot 10^{9} / \mathrm{L}$ was exceeded in 1.5 (for 10$)$ and 1.6 (for 8 ) times, respectively. The value of the reference drug methyluracil $(6.2 \pm 0.9) \cdot 10^{9} / \mathrm{L}$ was exceeded, respectively, in 1.3 (for 10) and 1.4 (for 8) times (Figure 1(a)).

The white blood cells count in the groups where 8 (6.5 \pm $0.8) \cdot 10^{9} / \mathrm{L}$ and $10(6.9 \pm 1.0) \cdot 10^{9} / \mathrm{L}$ were administrated 
appeared to be at the same level as for the group where methyluracil was administrated $(6.2 \pm 0.9) \cdot 10^{9} / \mathrm{L}$. None of the groups had the white blood cells count after 28 days of observation recovered to a value of intact animals (10.1 \pm 1.9$)$ $\cdot 10^{9} / \mathrm{L}$ (Figure 1(a)).

Statistical analysis of blood leukogram showed that cyclophosphamide solution causes a sharp decline of lymphocytes with an increasing of monocyte-eosinophile index. Administration of the bioactive compounds 3 and 8-11 stimulates the recovery of white blood cells subpopulations in peripheral blood comparable with methyluracil. The relative values of granulocytes after cyclophosphamide solution injection changed slightly, within the statistical error, and fluctuated in the range ( 48.4 to 52.1$) \%$, close to the value of intact animals (44.1 \pm 0.8$) \%$. On the 7 th, 21st, and 28 th day of observation there were no significant changes: $(32.2 \div 44.4) \%$, $(42.0 \div 49.6) \%$, and $(34.4 \div 54.9) \%$, respectively (Figure $1(\mathrm{~b})$ ). After 3 days of administration of cyclophosphamide the relative lymphocyte ratio dropped to the critical values (21.1 $\div 29.1) \%$ against the value of intact animals $(50.9 \pm 2.3) \%$, that is, in $2.4 \div 1.7$ times $(p \leq 0.05)$. The introduction of the bioactive compounds $\mathbf{3}$ and $\mathbf{8}$-11 stimulates lymphocyte pool proliferation activity and the release of agranulocytes into peripheral blood. Already on the 7th day of observation the relative lymphocyte ratio in the group $\mathbf{1 0}$ administration turned out to be $(39.6 \pm 3.0) \%$ against the values of the control group $(10.4 \pm 0.1) \%(p \leq 0.05)$ and the values of the group of methyluracil administration $(30.1 \pm 0.3) \%$ (Figure 1(d)). On the 21st day of observation the increase in the relative lymphocytic index was recorded. It was in the range of $(41.2 \div 35.1) \%$ compared to the reference value $(12.4 \pm 0.1) \%(p \leq 0.05)$ (Figure 1(d)). And on the 28th day of observation the relative lymphocyte ratio in the group where 10 was administrated was $(44.4 \pm 0.4) \%$ and where 8 was administrated was $(43.1 \pm 0.4) \%$, against the value of the group where methyluracil was administrated $(36.8 \pm 0.3) \%$ and the value of intact animals was $(54.4 \pm 0.5) \%$ (Figure $1(\mathrm{~d})$ ).

The value of the relative monocyte-eosinophile index increased: at the 1st day of observation it was $(22.5 \div 28.4) \%$ compared to the value of intact animals $(5.1 \pm 0,01) \%(p \leq$ $0.01)$, at the 7 th day of observation it was $(27.2 \div 36.6) \%$ against the value of intact animals $(4.4 \pm 0.01) \%$, and then on the 28th day of observation it fell to $(8.4 \div 9.4) \%$ against the values of the control group $(32.5 \pm 1.3) \%(p \leq 0.01)$ and the intact group $(3.2 \pm 0.01) \%$ (Figure 1(c)). Thus, the data obtained by analysis of the blood hemogram showed that the compounds $\mathbf{3}$ and 8-11 stimulate release of leukocyte cells in the peripheral blood at the same level as methyluracil does.

The data about the total leukocyte count, relative granulocyte index, relative monocytic-eosinophilic index, and relative lymphocyte index of the blood hemogram are represented in Tables S2-S5 in Supplementary Materials.

The more explicit effect of stimulation of proliferative activity of immune cells was obtained from the mice's bone marrow investigation. For this study the compounds 3,9 , and 11 which have shown the highest activity were selected.

The one single intraperitoneal injection of cyclophosphamide $160 \mathrm{mg} / \mathrm{kg}$ resulted in suppression of bone marrow hematopoiesis. The level of myeloid cells during the first days of observation was $(5.2 \div 6.8) \cdot 10^{6}$ cells $/ \mu \mathrm{L}$ (Figure $2(\mathrm{a})$ ) Cyclophosphamide showed significant cytostatic effect on the red blood cells and lymphocyte cells pools. The lymphoid cells subpopulation reached close to zero values at the first day of observation $(0.2 \div 0.3) \cdot 10^{6}$ cells $/ \mu \mathrm{L}$, which is 19.5 times below the value for intact animals ( $p \leq 0.01$ ) (Figure 2(b)). There was a sharp decrease in activity of erythroid pool in all the groups. The level of erythrocyte cells fell 4.3 times to $(1.3 \div 1.5)$ $\cdot 10^{6}$ cells $/ \mu \mathrm{L}(p \leq 0.01)$ and had not recovered to the value of intact animals during the entire period of observation (Figure 2(d)). The sharp decline was not recorded in a pool of granulocytic cells, and it had much faster restoring and on the 4th day of observation the values of control group almost approached the values of intact animals (Figure 2(c)).

Three-day administration of $\mathbf{3 , 9}$, and $\mathbf{1 1}$ causes a slow but steady increase (compared with the control group) in the amounts of nucleated cells. Recovery has been slow for myeloid cells (Figure 2(a)). On the first day of observation the mitotic activity of bone marrow at the myeloid karyocyte cell pool was as low as $(5.2 \div 6.8) \cdot 10^{6}$ cells $/ \mu$ L. Starting from the 14th day of observation in the groups of 3,9 , and 11 administration the increase of the proliferative activity $(18.5 \div 18.8) \cdot 10^{6}$ cells $/ \mu$ L was detected. On the 21 st day of observation the myeloid cells were close to the values of intact animals $(20.4 \div 21.2) \cdot 10^{6}$ cells $/ \mu \mathrm{L}$ (Figure $2(\mathrm{a})$ ). Over the all days of observation in the group where $\mathbf{1 1}$ was administrated the mice bone marrow myeloid cells exceeded the value of all the other experimental groups. On the 28th day of observation in the group where 11 was administrated the level of nucleated cells became $(23.4 \pm 0.05) \cdot 10^{6}$ cells $/ \mu \mathrm{L}$ against $(16.5 \pm 0.06) \cdot 10^{6}$ cells $/ \mu \mathrm{L}$ in control $(p \leq 0.05)$, exceeding 1.4 times (Figure 2(a)), and exceeding 1.22 times the group where methyluracil was administrated.

The compounds 3 and 9 are inferior to 11 but exceeded the reference drug methyluracil 1.2 and 1.1 times, respectively.

Subpopulation of lymphocytic cells appeared to be close to zero at the first day of observation $(0.2 \div 0.3) \cdot 10^{6}$ cells $/ \mu \mathrm{L}$, which is 19.5 times below the level of intact animals ( $p \leq$ 0.01 ) (Figure $2(\mathrm{~b})$ ). The start of positive dynamics was registered at the 8th day of observation (the 5th day after the administration of bioactive compounds). And on the 28th day of observation (25th day after the administration bioactive compounds) the highest value was observed in the group of $\mathbf{1 1}$ administration, accounting for $(5.2 \pm 0.03)$. $10^{6}$ cells $/ \mu \mathrm{L}$ against $(2.4 \pm 0.02) \cdot 10^{6}$ cells $/ \mu \mathrm{L}$ in the control group ( $p \leq 0.05$ ), exceeding 2.2 times the control group $(p \leq 0.05)$ (Figure 2(b)). The compounds 3 and 9 are inferior to 11 but exceeded the reference drug methyluracil 1.6 and 2.0 times, respectively.

Also, distinguishable difference was observed in the amount of granulocytic cells. Already on the 8th day of observation (the 5th day after administration) in the groups of the bioactive compounds administration the level of granulocytic cells $(6.2 \div 9.8) \cdot 10^{6}$ cells $/ \mu \mathrm{L}$ has reached the value of intact animal's cells $(8.5 \pm 0.8) \cdot 10^{6}$ cells $/ \mu \mathrm{L}$. On the 14 th day of observation the mitotic activity of granulocyte cell pool in the groups of the bioactive compounds administration (8.4 $\div 9.4) \cdot 10^{6}$ cells $/ \mu \mathrm{L}$ appeared to be higher than the mitotic 


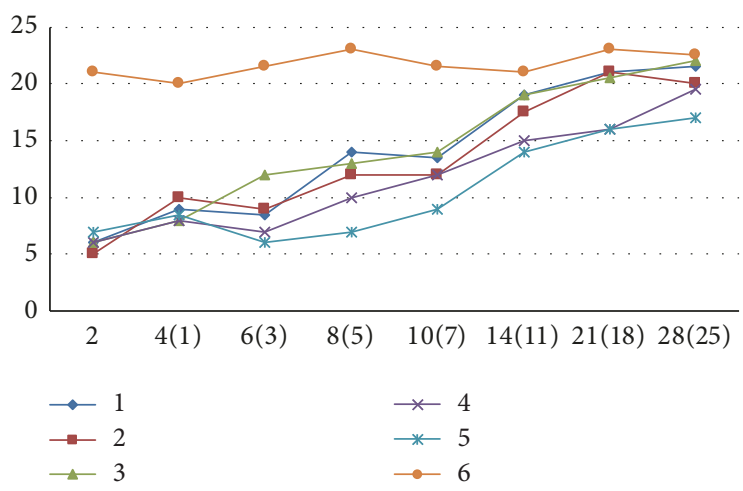

(a)

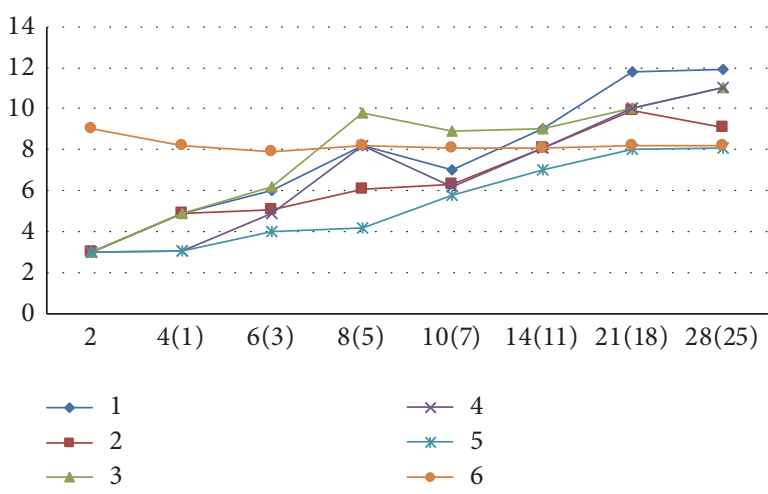

(c)

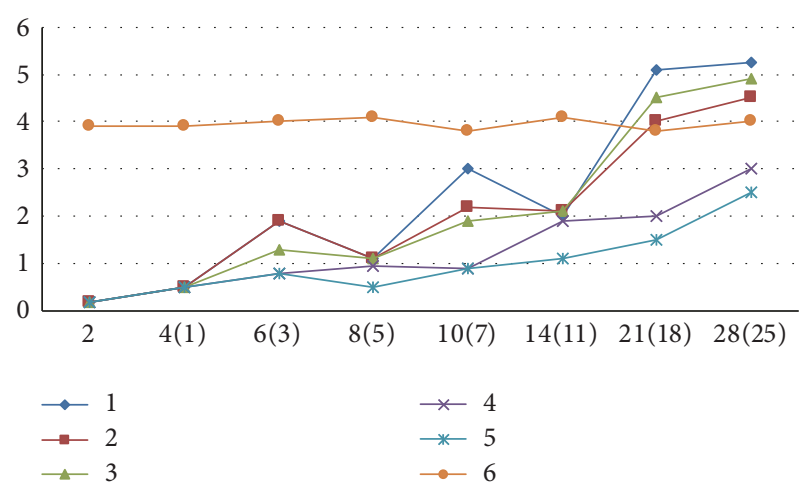

(b)

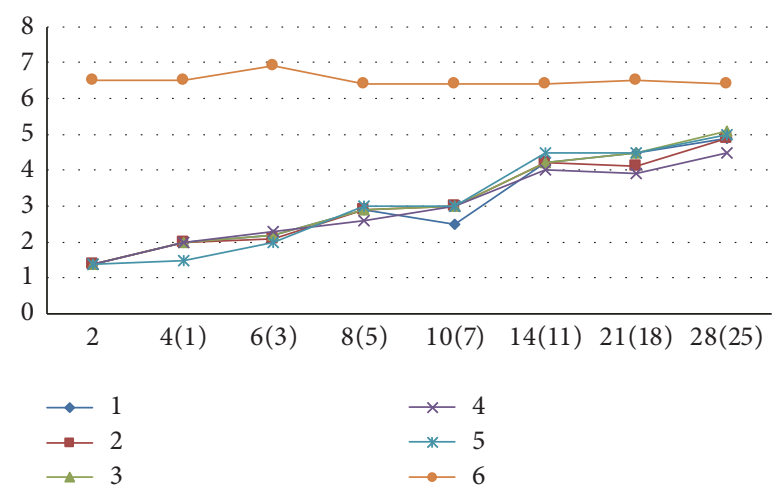

(d)

Figure 2: Myelogram of myeloid cells (a), the lymphoid cells (b), the granulocyte cells (c), and the erythrocyte cells (d) in the mice bone marrow, administration of $\mathbf{1 1}$ after the injection of cyclophosphamide solution (1), administration of $\mathbf{6}$ after the injection of cyclophosphamide solution (2), administration of $\mathbf{9}$ after the injection of cyclophosphamide solution (3), administration of methyluracil after the injection of cyclophosphamide solution (4), control group (administration of placebo (saline) after the injection of cyclophosphamide solution) (5), and intact animals (6). Time in days, in parentheses, days after administration of the compounds (the abscissa axis); number of cells $\cdot 10^{6} / \mu \mathrm{L}$ (the axes of ordinates).

activity of intact animals $(8.2 \pm 0.8) \cdot 10^{6}$ cells $/ \mu \mathrm{L}$ (Figure 2(c)). Throughout the entire period of observation, compounds 9 and $\mathbf{1 1}$ exceeded the activity of $\mathbf{3}$ and the activity of reference drug.

Cyclophosphamide has expressed a pronounced myelosuppressive effect on the proliferation of erythrocyte cells. In all the groups of observation slow recovery of erythropoiesis was detected, but not in one of the groups the level of erythrocyte pool has reached the value of intact animals during the entire period of observation (Figure 2(d)). No significant differences between the groups of the bioactive compounds administration, the control (placebo), and methyluracil administrated group were observed.

The data about the monocyte index, myelokaryocytic index, granulocyte index, and the total erythrocyte index of bone marrow myelogram are represented in Tables S6-S9 in Supplementary Materials.

\section{Experimental}

4.1. 1-(2-Ethoxyethyl)-4-hydroxypiperidine-4-carbonitrile (2). A mixture of $1.7 \mathrm{~g}(0.01 \mathrm{~mol})$ of 1-(2-ethoxyethyl) piperidine4-one (1) and $1 \mathrm{~mL}(0.01 \mathrm{~mol})$ acetone cyanohydrins was maintained for 15 hours at room temperature. The white precipitate was then recrystallized from ethyl acetate. $1.15 \mathrm{~g}$ of 1-(2-ethoxyethyl)-4-hydroxypiperidine4-carbonitrile (2) $(67.5 \%$ yield $)$ was obtained, m.p. $75-77^{\circ} \mathrm{C}$. IR $(\mathrm{KBr}): 3520 \mathrm{~cm}^{-1}(\mathrm{O}-\mathrm{H}) ; 3329$ (broad, N$\mathrm{H}) ; 2232 \mathrm{~cm}^{-1}(\mathrm{C} \equiv \mathrm{N}) .{ }^{13} \mathrm{C} \mathrm{NMR}\left(\mathrm{CDCl}_{3}\right) \delta$, ppm: $121.3(\mathrm{~s}$, $\mathrm{C} \equiv \mathrm{N}) ; 67.4\left(\mathrm{t}, \mathrm{CH}_{2} \mathrm{CH}_{2} \mathrm{OCH}_{2} \mathrm{CH}_{3}\right) ; 66.7$ (s, C-4); $66.1(\mathrm{t}$, $\left.\mathrm{CH}_{2} \mathrm{CH}_{2} \mathrm{OCH}_{2} \mathrm{CH}_{3}\right) ; 56.8\left(\mathrm{t}, \mathrm{CH}_{2} \mathrm{CH}_{2} \mathrm{OCH}_{2} \mathrm{CH}_{3}\right) ; 49.2$ (t, C-2, C-6); 36.5 (t, C-3, C-5); 14.7 (q, $\mathrm{CH}_{2} \mathrm{CH}_{2} \mathrm{OCH}_{2} \mathrm{CH}_{3}$ ). $1 \mathrm{H}$ NMR $\left(\mathrm{CDCl}_{3}\right) \delta$, ppm: $1.18\left(\mathrm{t}, \mathrm{CH}_{2} \mathrm{CH}_{2} \mathrm{OCH}_{2} \mathrm{CH}_{3}\right)$; $1.86\left(\mathrm{~m}, \mathrm{H}_{\mathrm{a}}-3, \mathrm{H}_{\mathrm{a}}-5\right) ; 2.08\left(\mathrm{~m}, \mathrm{H}_{\mathrm{e}}-3, \mathrm{H}_{\mathrm{e}}-5\right) ; 2.40\left(\mathrm{~m}, \mathrm{H}_{\mathrm{a}}-2\right.$, $\left.\mathrm{H}_{\mathrm{a}}-6\right) ; 2.52\left(\mathrm{~m}, \mathrm{H}_{\mathrm{e}}-2, \mathrm{H}_{\mathrm{e}}-6\right) ; 2.56\left(\mathrm{t}, \mathrm{CH}_{2} \mathrm{CH}_{2} \mathrm{OCH}_{2} \mathrm{CH}_{3}\right)$; 2.58 (broadened s, OH); 3.51 (q, $\mathrm{CH}_{2} \mathrm{CH}_{2} \mathrm{OCH}_{2} \mathrm{CH}_{3}$ ); 3.59 (t, $\mathrm{CH}_{2} \mathrm{CH}_{2} \mathrm{OCH}_{2} \mathrm{CH}_{3}$ ). Anal. calcd. for $\mathrm{C}_{10} \mathrm{H}_{18} \mathrm{~N}_{2} \mathrm{O}_{2}, \%$ : C, 60.58; H, 9.15; N, 14.13. Found, \%: C, 60.81; H, 9.06; N, 14.03 .

4.2. 8-(2-Ethoxyethyl)-1,3,8-triazaspiro[4.5]decane-2,4-dione Hydrochloride $(3 \cdot \mathbf{H C l})$. A solution of $1.5 \mathrm{~g}(0.008 \mathrm{~mol}) 1-$ (2-ethoxyethyl)-4-hydroxypiperidine-4-carbonitrile (2) and $1.5 \mathrm{~g}(0.016 \mathrm{~mol})$ ammonium carbonate in $75 \mathrm{~mL}$ of water was heated at $50^{\circ} \mathrm{C}$ with constant stirring within 3 hours. Then the 
water was evaporated at $15 \mathrm{mmHg}$ and the residue was washed with benzene and dissolved in methanol. The methanol solution was acidified with isopropanolic $\mathrm{HCl}$ until acidic $\mathrm{pH}$, and the inorganic precipitate falls out. The filtered solution was evaporated to dryness. The residue was recrystallized from methanol. $0.5 \mathrm{~g}$ (24\% yield) of 8-(2-ethoxyethyl-)-1,3,8triazaspiro[4.5]decane-2,4-dione $(3 \cdot \mathrm{HCl})$ was obtained. M.p. 282-284 ${ }^{\circ} \mathrm{C}$. Anal. calcd. for $\mathrm{C}_{11} \mathrm{H}_{20} \mathrm{ClN}_{3} \mathrm{O}_{3}, \%$ : C, 47.57; $\mathrm{H}$, 7.26; N, 15.13; Cl, 12.76. Found, \%: C, 47.70; H, 7.16; N, 15.25; $\mathrm{Cl}, 12.85$.

4.3. General Method for the Synthesis of 8-(2-Ethoxyethyl3-ethoxypropyl-3-butoxypropyl-)-6-(H, methyl)-1,3,8-triazaspiro[4.5]decane-2,4-diones $(\mathbf{3}, \mathbf{8}-\mathbf{1 1})$. Into a glass vial ammonium carbonate, sodium cyanide and the corresponding 4oxopiperidine $(1,4-7)$ in the water-alcohol solution $(1: 1)$ were placed. The vial was sealed and heated on a steam bath within 4 hours at $75^{\circ} \mathrm{C}$. The vial was then cooled to $0^{\circ} \mathrm{C}$ and carefully opened; the contents poured into a beaker and treated while stirring with $3 \%$ hydrochloric acid to $\mathrm{pH} \sim 6$. The resulting solution was evaporated to dryness under the water pump vacuum. The residue was triturated with alumina and placed on a column with alumina. The product was first eluted with benzene ethanol $(4: 1)$ and then with a mixture of these solvents at a ratio of $1: 1$. The selected fractions were combined and the solvent was distilled off.

4.3.1. 8-(2-Ethoxyethyl)-1,3,8-triazaspiro[4.5]decane-2,4-dione (3). $2.8 \mathrm{~g}$ was obtained, (29\% yield). M.p. $172-173^{\circ} \mathrm{C}$. IR (KBr), $\mathrm{cm}^{-1}: 1740,1700 \mathrm{~cm}^{-1}(\mathrm{C}=\mathrm{O}), 1110 \mathrm{~cm}^{-1}$ (C-O-C). ${ }^{13} \mathrm{C}$ $\operatorname{NMR}\left(\mathrm{CDCl}_{3}\right) \delta$, ppm: $178.4(\mathrm{~s}, \mathrm{C}-4) ; 158.3$ (s, C-2); 67.2 (s, C5); $67.1\left(\mathrm{t}, \mathrm{CH}_{2} \mathrm{CH}_{2} \mathrm{OCH}_{2} \mathrm{CH}_{3}\right) ; 66.0\left(\mathrm{t}, \mathrm{CH}_{2} \mathrm{CH}_{2} \mathrm{OCH}_{2} \mathrm{CH}_{3}\right)$; $57.1\left(\mathrm{t}, \mathrm{CH}_{2} \mathrm{CH}_{2} \mathrm{OCH}_{2} \mathrm{CH}_{3}\right) ; 48.9$ (t, C-7, C-9); 30.1 (C6, C-10); $14.4\left(\mathrm{q}, \mathrm{CH}_{2} \mathrm{CH}_{2} \mathrm{OCH}_{2} \mathrm{CH}_{3}\right) \cdot 1 \mathrm{H} \mathrm{NMR}\left(\mathrm{CDCl}_{3}\right)$ $\delta$, ppm: $1.18\left(\mathrm{t}, \mathrm{CH}_{2} \mathrm{CH}_{2} \mathrm{OCH}_{2} \mathrm{CH}_{3}\right) ; 1.84\left(\mathrm{~m}, \mathrm{H}_{\mathrm{a}}-6, \mathrm{H}_{\mathrm{a}}-\right.$ 10); $2.07\left(\mathrm{~m}, \mathrm{H}_{\mathrm{e}}-6, \mathrm{H}_{\mathrm{e}}-10\right) ; 2.38\left(\mathrm{~m}, \mathrm{H}_{\mathrm{a}}-7, \mathrm{H}_{\mathrm{a}}-9\right) ; 2.56(\mathrm{t}$, $\left.\mathrm{CH}_{2} \mathrm{CH}_{2} \mathrm{OCH}_{2} \mathrm{CH}_{3}\right) ; 3.52\left(\mathrm{q}, \mathrm{CH}_{2} \mathrm{CH}_{2} \mathrm{OCH}_{2} \mathrm{CH}_{3}\right) ; 3.55$ (m, $\mathrm{H}_{\mathrm{e}}-7, \mathrm{H}_{\mathrm{e}}-9$ ); 3.59 (t, $\mathrm{CH}_{2} \mathrm{CH}_{2} \mathrm{OCH}_{2} \mathrm{CH}_{3}$ ); 6.84 (s, H-1); 7.23 (s, H-3). Anal. calcd. for $\mathrm{C}_{11} \mathrm{H}_{19} \mathrm{~N}_{3} \mathrm{O}_{3}, \%$ : C, 54.76; H, 7.94; N, 17.41. Found, \%: C, 54.87; H, 8.06; N, 17.53.

4.3.2. 8-(2-Ethoxyethyl-)-6-methyl-1,3,8-triazaspiro[4.5]decane2,4-dione (8). $5.2 \mathrm{~g}$ was obtained, (54\% yield). M.p. 154$155^{\circ} \mathrm{C}$. IR (KBr), cm ${ }^{-1}: 3330$ (broad, N-H); 1730, $1700(\mathrm{C}=\mathrm{O})$; 1105 (C-O-C). ${ }^{13} \mathrm{C}$ NMR $\left(\mathrm{CDCl}_{3}\right) \delta$, ppm: 183.2 (s, C-4, 1/2 $W=12 \mathrm{~Hz}) ; 162.3(\mathrm{~s}, \mathrm{C}-2) ; 67.9\left(\mathrm{t}, \mathrm{CH}_{2} \mathrm{CH}_{2} \mathrm{OCH}_{2} \mathrm{CH}_{3}\right)$; 66.9 (s, C-5); $66.5\left(\mathrm{t}, \mathrm{CH}_{2} \mathrm{CH}_{2} \mathrm{OCH}_{2} \mathrm{CH}_{3}\right) ; 58.4$ (t, $\mathrm{CH}_{2} \mathrm{CH}_{2} \mathrm{OCH}_{2} \mathrm{CH}_{3}$ ); 57.6 (t, C-7); 49.7 (C-9); 35.9 (d, C-6); 33.8 (t, C-10); 15.6 (q, $\left.\mathrm{CH}_{2} \mathrm{CH}_{2} \mathrm{OCH}_{2} \mathrm{CH}_{3}\right) ; 12.9$ (q, 6- $\left.\mathrm{CH}_{3}, 1 / 2 W=6 \mathrm{~Hz}\right) .{ }^{1} \mathrm{H} \mathrm{NMR}\left(\mathrm{CDCl}_{3}\right) \delta$, ppm: 0.96 $\left(\mathrm{d}, 6-\mathrm{CH}_{3}\right) ; 1.17\left(\mathrm{t}, \mathrm{CH}_{2} \mathrm{CH}_{2} \mathrm{OCH}_{2} \mathrm{CH}_{3}\right) ; 1.77\left(\mathrm{H}_{\mathrm{a}}-6\right) ; 1.84$ $\left(\mathrm{H}_{\mathrm{a}}-10\right) ; 1.96\left(\mathrm{H}_{\mathrm{e}}-10\right) ; 2.08\left(\mathrm{t}, \mathrm{H}_{\mathrm{a}}-7\right) ; 2.31\left(\mathrm{H}_{\mathrm{a}}-9\right) ; 2.59(\mathrm{t}$, $\left.\mathrm{CH}_{2} \mathrm{CH}_{2} \mathrm{OCH}_{2} \mathrm{CH}_{3}\right) ; 2.61\left(\mathrm{t}, \mathrm{H}_{\mathrm{e}}-7\right) ; 2.83\left(\mathrm{H}_{\mathrm{e}}-9\right) ; 3.51$ (q, $\left.\mathrm{CH}_{2} \mathrm{CH}_{2} \mathrm{OCH}_{2} \mathrm{CH}_{3}\right) ; 3.59\left(\mathrm{t}, \mathrm{CH}_{2} \mathrm{CH}_{2} \mathrm{OCH}_{2} \mathrm{CH}_{3}\right) ; 7.34$ (s, $\mathrm{H}-1$ ); 8.02 (s, H-3). Anal. calcd. for $\mathrm{C}_{12} \mathrm{H}_{21} \mathrm{~N}_{3} \mathrm{O}_{3}, \%$ : C, 56.45; $\mathrm{H}, 8.29 ; \mathrm{N}, 16.46$. Found, \%: C, 56.35; H, 8.28; N, 16.46 .

4.3.3. 8-(3-Ethoxypropyl)-6-methyl-1,3,8-triazaspiro[4.5]decane2,4-dione (9). $2.3 \mathrm{~g}$ was obtained (35\% yield) as a viscous oil.
Hydrochloride: M.p. 185-186 ${ }^{\circ}$ C. IR (KBr), $\mathrm{cm}^{-1}$ : 3333 (broad, $\mathrm{N}-\mathrm{H}) ; 1722,(\mathrm{C}=\mathrm{O}) ; 1120(\mathrm{C}-\mathrm{O}-\mathrm{C}) .{ }^{13} \mathrm{C} \mathrm{NMR}\left(\mathrm{CDCl}_{3}\right) \delta$, ppm: 175.5 (s, C-4); 156.5 (s, C-2); 68.6 (s, C-5); 67.1 (t, $\mathrm{CH}_{2} \mathrm{CH}_{2}$ $\left.\mathrm{CH}_{2} \mathrm{OCH}_{2} \mathrm{CH}_{3}\right) ; 66.5\left(\mathrm{t}, \mathrm{CH}_{2} \mathrm{CH}_{2} \mathrm{CH}_{2} \mathrm{OCH}_{2} \mathrm{CH}_{3}\right) ; 61.1(\mathrm{t}$, $\mathrm{CH}_{2} \mathrm{CH}_{2} \mathrm{CH}_{2} \mathrm{OCH}_{2} \mathrm{CH}_{3}$ ); 55.7 (t, C-7); 53.9 (t, C-9); 34.6 (d, C-6); 30.7 (t, C-10); 24.4 (t, $\mathrm{CH}_{2} \mathrm{CH}_{2} \mathrm{CH}_{2} \mathrm{OCH}_{2} \mathrm{CH}_{3}$ ); 13.2 (q, $\left.\mathrm{CH}_{2} \mathrm{CH}_{2} \mathrm{CH}_{2} \mathrm{OCH}_{2} \mathrm{CH}_{3}\right) ; 12.6$ (q, 6- $\mathrm{CH}_{3}$ ). ${ }^{1} \mathrm{H}$ NMR $\left(\mathrm{CDCl}_{3}\right) \delta$, ppm: $0.98\left(\mathrm{~d}, 6-\mathrm{CH}_{3}\right) ; 1.18(\mathrm{t}$, $\left.\mathrm{CH}_{2} \mathrm{CH}_{2} \mathrm{CH}_{2} \mathrm{OCH}_{2} \mathrm{CH}_{3}\right) ; 1.58\left(\mathrm{CH}_{2} \mathrm{CH}_{2} \mathrm{CH}_{2} \mathrm{OCH}_{2} \mathrm{CH}_{3}\right)$; $1.69\left(\mathrm{H}_{\mathrm{a}}-6\right) ; 1.80\left(\mathrm{H}_{\mathrm{a}}-10\right) ; 2.01\left(\mathrm{H}_{\mathrm{e}}-10\right) ; 2.21\left(\mathrm{t}, \mathrm{H}_{\mathrm{a}}-7\right) ; 2.41$ $\left(\mathrm{H}_{\mathrm{a}}-9\right) ; 2.45\left(\mathrm{CH}_{2} \mathrm{CH}_{2} \mathrm{CH}_{2} \mathrm{OCH}_{2} \mathrm{CH}_{3}\right) ; 2.64\left(\mathrm{t}, \mathrm{H}_{\mathrm{e}}-7\right)$; $2.78\left(\mathrm{H}_{\mathrm{e}}-9\right) ; 3.54$ (q, $\left.\mathrm{CH}_{2} \mathrm{CH}_{2} \mathrm{CH}_{2} \mathrm{OCH}_{2} \mathrm{CH}_{3}\right) ; 3.62(\mathrm{t}$, $\mathrm{CH}_{2} \mathrm{CH}_{2} \mathrm{CH}_{2} \mathrm{OCH}_{2} \mathrm{CH}_{3}$ ); 7.03 (s, H-1); 8.39 (s, H-3). Anal. calcd. for $\mathrm{C}_{13} \mathrm{H}_{24} \mathrm{~N}_{3} \mathrm{O}_{3} \mathrm{Cl}$, \%: C, 51.06; $\mathrm{H}, 7.91 ; \mathrm{N}, 13.74 ; \mathrm{Cl}$, 11.59. Found, \%: C, 50.99; H, H 8.00; N, 13.64; Cl, 11.49 .

4.3.4. 8-(3-Butoxypropyl-)-1,3,8-triazaspiro[4.5]decane-2,4dione (10). $3.7 \mathrm{~g}$ was obtained (40\% yield). M.p. $102-106^{\circ} \mathrm{C}$. IR $(\mathrm{KBr}), \mathrm{cm}^{-1}$ : 3331 (broad, N-H); 1750, $1710(\mathrm{C}=\mathrm{O}) ; 1110$ (C-O-C). ${ }^{13} \mathrm{C} \mathrm{NMR}\left(\mathrm{CDCl}_{3}\right) \delta$, ppm: 179.4 (s, C-4); 157.3 (s, C-2); 70.4 (t, $\mathrm{CH}_{2} \mathrm{CH}_{2} \mathrm{CH}_{2} \mathrm{OCH}_{2} \mathrm{CH}_{2} \mathrm{CH}_{2} \mathrm{CH}_{3}$ ); 68.7 (t, $\mathrm{CH}_{2} \mathrm{CH}_{2} \mathrm{CH}_{2} \mathrm{OCH}_{2} \mathrm{CH}_{2} \mathrm{CH}_{2} \mathrm{CH}_{3}$ ); 67.7 (s, C-5); 56.0 (t, C-7, C-9); 55.3 (t, $\mathrm{CH}_{2} \mathrm{CH}_{2} \mathrm{CH}_{2} \mathrm{OCH}_{2} \mathrm{CH}_{2} \mathrm{CH}_{2} \mathrm{CH}_{3}$ ); 36.1 (t, C-6, C-10); 31.7 (t, $\left.\mathrm{CH}_{2} \mathrm{CH}_{2} \mathrm{CH}_{2} \mathrm{OCH}_{2} \mathrm{CH}_{2} \mathrm{CH}_{2} \mathrm{CH}_{3}\right)$; $27.2 \quad\left(t, \quad \mathrm{CH}_{2} \mathrm{CH}_{2} \mathrm{CH}_{2} \mathrm{OCH}_{2} \mathrm{CH}_{2} \mathrm{CH}_{2} \mathrm{CH}_{3}\right) ; \quad 19.2$ (t, $\quad \mathrm{CH}_{2} \mathrm{CH}_{2} \mathrm{CH}_{2} \mathrm{OCH}_{2} \mathrm{CH}_{2} \mathrm{CH}_{2} \mathrm{CH}_{3}$ ); $13.6 \quad$ (q, $\left.\mathrm{CH}_{2} \mathrm{CH}_{2} \mathrm{CH}_{2} \mathrm{OCH}_{2} \mathrm{CH}_{2} \mathrm{CH}_{2} \mathrm{CH}_{3}\right) .{ }^{1} \mathrm{H} \quad \mathrm{NMR} \quad\left(\mathrm{CDCl}_{3}\right)$ $\delta$, ppm: $0.84 \quad\left(\mathrm{CH}_{2} \mathrm{CH}_{2} \mathrm{CH}_{2} \mathrm{OCH}_{2} \mathrm{CH}_{2} \mathrm{CH}_{2} \mathrm{CH}_{3}\right)$; 1.41-1.56 ( $\left.\mathrm{CH}_{2} \mathrm{CH}_{2} \mathrm{CH}_{2} \mathrm{OCH}_{2} \mathrm{CH}_{2} \mathrm{CH}_{2} \mathrm{CH}_{3}\right) ; 1.79-1.81$ $\left(\mathrm{H}_{\mathrm{a}}-6, \mathrm{H}_{\mathrm{a}}-10\right) ; 2.10-2.22\left(\mathrm{H}_{\mathrm{e}}-6, \mathrm{H}_{\mathrm{e}}-10\right) ; 2.31\left(\mathrm{~m}, \mathrm{H}_{\mathrm{a}}-7\right.$, $\left.\mathrm{H}_{\mathrm{a}}-9\right) ; \quad 2.49 \quad\left(\mathrm{CH}_{2} \mathrm{CH}_{2} \mathrm{CH}_{2} \mathrm{OCH}_{2} \mathrm{CH}_{2} \mathrm{CH}_{2} \mathrm{CH}_{3}\right) ; \quad 3.53$ $\left(\mathrm{CH}_{2} \mathrm{CH}_{2} \mathrm{CH}_{2} \mathrm{OCH}_{2} \mathrm{CH}_{2} \mathrm{CH}_{2} \mathrm{CH}_{3}\right) ; 3.56\left(\mathrm{~m}, \mathrm{H}_{\mathrm{e}}-7, \mathrm{H}_{\mathrm{e}}-9\right)$; 3.61 (t, $\mathrm{CH}_{2} \mathrm{CH}_{2} \mathrm{CH}_{2} \mathrm{OCH}_{2} \mathrm{CH}_{2} \mathrm{CH}_{2} \mathrm{CH}_{3}$ ); 7.15 (s, H-1); 8.58 (s, H-3). Anal. calcd. for $\mathrm{C}_{14} \mathrm{H}_{25} \mathrm{~N}_{3} \mathrm{O}_{3}, \%$ : C, 59.34; H, 8.89; $\mathrm{N}, 14.83$. Found, \%: C, 59.55; H, 8.85; N, 14.87 .

4.3.5. 8-(3-Butoxypropyl-)-6-methyl-1,3,8-triazaspiro[4.5]decane2,4-dione (11). $8.7 \mathrm{~g}$ was obtained, (61\% yield). M.p. 121-124 ${ }^{\circ} \mathrm{C}$. IR (KBr), cm ${ }^{-1}$ : 3333 (broad, N-H); 1775, $1743(\mathrm{C}=\mathrm{O}) ; 1120$ (C-O-C). ${ }^{13} \mathrm{C}$ NMR $\left(\mathrm{CDCl}_{3}\right) \quad \delta$, ppm: 178.6 (s, C-4, 1/2 W = $14 \mathrm{~Hz}) ; 159.2$ (s, C-2); $70.6 \quad\left(t, \mathrm{CH}_{2} \mathrm{CH}_{2} \quad \mathrm{CH}_{2} \mathrm{OCH}_{2} \quad \mathrm{CH}_{2} \mathrm{CH}_{2} \mathrm{CH}_{3}\right) ; 68.9 \quad(\mathrm{t}$, $\mathrm{CH}_{2} \mathrm{CH}_{2} \mathrm{CH}_{2} \mathrm{OCH}_{2} \mathrm{CH}_{2} \mathrm{CH}_{2} \mathrm{CH}_{3}$ ); 65.7 (s, C-5); 56.4 (t, C-7); 55.1 (t, $\left.\quad \mathrm{H}_{2} \mathrm{CH}_{2} \mathrm{CH}_{2} \mathrm{OCH}_{2} \mathrm{CH}_{2} \mathrm{CH}_{2} \mathrm{CH}_{3}\right)$; $49.8 \quad(\mathrm{t}, \quad \mathrm{C}-9) ; \quad 35.4 \quad(\mathrm{~d}, \quad \mathrm{C}-6) ; 34.0 \quad$ (t, $\mathrm{C}-10)$; $31.7 \quad\left(t, \quad \mathrm{CH}_{2} \mathrm{CH}_{2} \mathrm{CH}_{2} \mathrm{OCH}_{2} \mathrm{CH}_{2} \mathrm{CH}_{2} \mathrm{CH}_{3}\right) ; \quad 27.1$

(t, $\quad \mathrm{CH}_{2} \mathrm{CH}_{2} \quad \mathrm{CH}_{2} \mathrm{OCH}_{2} \mathrm{CH}_{2} \mathrm{CH}_{2} \mathrm{CH}_{3}$ ); $\quad 19.2$

(t, $\quad \mathrm{CH}_{2} \mathrm{CH}_{2} \mathrm{CH}_{2} \mathrm{OCH}_{2} \mathrm{CH}_{2} \mathrm{CH}_{2} \mathrm{CH}_{3}$ ); 13.8 (q, $\mathrm{CH}_{2} \mathrm{CH}_{2} \mathrm{CH}_{2} \mathrm{OCH}_{2} \mathrm{CH}_{2} \mathrm{CH}_{2} \mathrm{CH}_{3}$ ); 12.6 (q, 6- $\mathrm{CH}_{3}$, $1 / 2 W=6 \mathrm{~Hz}) .{ }^{1} \mathrm{H}$ NMR $\left(\mathrm{CDCl}_{3}\right) \quad \delta, \quad$ ppm: 0.87 $\left(\mathrm{CH}_{2} \mathrm{CH}_{2} \mathrm{CH}_{2} \mathrm{OCH}_{2} \mathrm{CH}_{2} \mathrm{CH}_{2} \mathrm{CH}_{3}\right) ; 0.99$ (d, 6- $\left.\mathrm{CH}_{3}\right)$; 1.45-1.56 $\left(\mathrm{CH}_{2} \mathrm{CH}_{2} \mathrm{CH}_{2} \mathrm{OCH}_{2} \mathrm{CH}_{2} \mathrm{CH}_{2} \mathrm{CH}_{3}\right) ; 1.71 \quad\left(\mathrm{H}_{\mathrm{a}}-\right.$ 6); $1.83\left(\mathrm{H}_{\mathrm{a}}-10\right) ; 2.21\left(\mathrm{H}_{\mathrm{e}}-10, \mathrm{H}_{\mathrm{a}}-7\right) ; 2.41\left(\mathrm{H}_{\mathrm{a}}-9\right) ; 2.47$ $\left(\mathrm{CH}_{2} \mathrm{CH}_{2} \mathrm{CH}_{2} \mathrm{OCH}_{2} \mathrm{CH}_{2} \mathrm{CH}_{2} \mathrm{CH}_{3}\right) ; 2.61\left(\mathrm{t}, \mathrm{H}_{\mathrm{e}}-7\right) ; 2.79$ $\left(\mathrm{H}_{\mathrm{e}}-9\right) ; 3.55\left(\mathrm{CH}_{2} \mathrm{CH}_{2} \mathrm{CH}_{2} \mathrm{OCH}_{2} \mathrm{CH}_{2} \mathrm{CH}_{2} \mathrm{CH}_{3}\right) ; 3.62(\mathrm{t}$, $\mathrm{CH}_{2} \mathrm{CH}_{2} \mathrm{CH}_{2} \mathrm{OCH}_{2} \mathrm{CH}_{2} \mathrm{CH}_{2} \mathrm{CH}_{3}$ ); 7.13 (s, H-1); 8.50 (s, $\mathrm{H}-3)$. Anal. calcd. for $\mathrm{C}_{15} \mathrm{H}_{27} \mathrm{~N}_{3} \mathrm{O}_{3}, \%$ : C, 60.58; $\mathrm{H}, 9.15 ; \mathrm{N}$, 14.13. Found, \%: C, 60.55; H, 9.21; N, 12.97 . 


\section{Conclusions}

All the bioactive compounds studied have shown the myelostimulating activity on the model of cyclophosphamideinduced myelodepression. Total leukocyte count of hemogram of the novel compounds $\mathbf{9}$ and $\mathbf{1 1}$ exceeded methyluracil in the activity by 32 and $40 \%$, respectively, and significantly accelerating the regeneration of granulocytes (by 11 and $44 \%$, resp.) and erythrocytes (by 15\%) of bone marrow hematopoiesis without affecting the erythropoiesis. The total leukocyte count of compounds $\mathbf{3}, \mathbf{8}$, and $\mathbf{1 0}$ is on level of reference drug methyluracil.

\section{Conflicts of Interest}

The authors declare that they have no conflicts of interest.

\section{Acknowledgments}

This work was financially supported by the Ministry of Education and Science of the Republic of Kazakhstan [Grant Applications AP051032833/GF5, AP05131025/GF5, BR05236800/PTF, BR0526302/PTF, and BR052344667/PTF].

\section{Supplementary Materials}

Table S1: values obtained for the intact control animals. Table S2: total leukocyte count $\left(\cdot 10^{9} / \mathrm{L}\right.$ of blood) of hemogram of animals after administration of the compounds 3 and 8-11. Table S3: the relative granulocyte index (\%) of the blood hemogram of animals after administration of the compounds 3 and $\mathbf{8 - 1 1}$. Table S4: the relative monocyticeosinophilic index (\%) of blood hemogram of animals after administration of the compounds 3 and 8-11. Table S5: the relative lymphocyte index (\%) of the blood hemogram of animals after administration of the compounds $\mathbf{3}$ and 8-11. Table S6: the monocyte index $\left(\cdot 10^{6} / \mu \mathrm{L}\right)$ of bone marrow myelogram of animals after administration of compounds 3, 9, and 11. Table S7: myelokaryocytic index $\left(\cdot 10^{6} / \mu \mathrm{L}\right)$ of bone marrow myelogram of animals after administration of compounds 3, 9, and 11. Table S8: the granulocyte index $\left(\cdot 10^{6} / \mu \mathrm{L}\right)$ of bone marrow myelogram of animals after administration of the compounds 3, 9, and 11. Table S9: the total erythrocyte index $\left(\cdot 10^{6} / \mu \mathrm{L}\right)$ of bone marrow myelogram of animals after administration of the compounds 3, 9, and 11. (Supplementary Materials)

\section{References}

[1] Q. Ashton Acton, Advances in Leukopenia research and treatment, Scholarly Editions, Atlanta, USA, 2012.

[2] C. Gibson and N. Berliner, "How we evaluate and treat neutropenia in adults," Blood, vol. 124, no. 8, pp. 1251-1258, 2014.

[3] V. K. Yu, A. D. Nagimova, K. D. Praliev, S. N. Shin, and N. De Kimpe, "ChemInform Abstract: Synthesis, Antibacterial and Analgesic Activity of 1-(2-Ethoxyethyl)-4-hydroxy(acyloxy)piperidine-4-carboxylic Acids.", ChemInform, vol. 33, no. 50, pp. no-no, 2002.

[4] A. Z. Kabdraisova, M. F. Faskhutdinov, V. K. Yu et al., "Synthesis and properties of $\mathrm{N}$-(2-ethoxyethyl) piperidine derivatives of anabasine," Chemistry of Natural Compounds, vol. 43, no. 4, pp. 437-440, 2007.

[5] V. K. Yu, A. Z. Kabdraissova, K. D. Praliyev, S. N. Shin, and K. D. Berlin, "Synthesis and properties of novel alkoxy- and phenoxyalkyl ethers of secondary and tertiary ethynyl-piperdin-4-ols possessing unusual analgesic, anti-bacterial, and antispasmotic activity as well as low toxicity," Journal of Saudi Chemical Society, vol. 13, no. 2, pp. 209-217, 2009.

[6] V. K. Yu, K. D. Praliev, E. E. Fomicheva, L. K. Baktybayeva, E. A. Svambayev, and S. T. Tuleukhanov, "Immunostimulants based on N-alkoxypiperidines," Khim. Zh. Kazakh, vol. 2, pp. 180-187, 2007.

[7] V. Yu, K. Praliyev, A. Nagimova, and A. Zazybin, "A simple one-pot synthesis of N-substituted 4-methyl-1-oxa-8-azaspiro[4,5]deca-3-en-3-carboxylic acids," Tetrahedron Letters, vol. 56, no. 13, pp. 1631-1634, 2015.

[8] P. Dumont and J. Poupaert, Sulfurated hydantoin derivatives and pharmaceutical compositions containing same, Patent US 4713390, 1987.

[9] “Anticonvulsant medications - hydantoin derivatives," USA, 2014, http://umm.edu/health/medical/altmed/depletion/anticonvulsant-medications-hydantoin-derivatives.

[10] S. H. Gregory, "Hydantoin derivative compounds, pharmaceutical compositions," and methods of using same, Article ID 6974823, 2005.

[11] Z. Rajic, B. Zorc, S. Raic-Malic et al., "Hydantoin derivatives of L- and D-amino acids: Synthesis and evaluation of their antiviral and antitumoral activity," Molecules, vol. 11, no. 11, pp. 837-848, 2006.

[12] S. Hmuda, N. Trišović, J. Rogan et al., "New derivatives of hydantoin as potential antiproliferative agents: Biological and structural characterization in combination with quantum chemical calculations," Monatshefte für Chemie, vol. 145, no. 5, pp. 821-833, 2014.

[13] F. Fujisaki, H. Aki, A. Naito et al., "Synthesis of new 5-substituted hydantoins and symmetrical twin-drug type hydantoin derivatives," Chemical \& Pharmaceutical Bulletin, vol. 62, no. 5, pp. 429-438, 2014.

[14] "Ethical principles and guidelines for scientific experiments on animals," Experientia, vol. 48, no. 1, pp. 1-3, 1992.

[15] M. F. Fransen, F. Ossendorp, R. Arens, and C. J. M. Melief, "Local immunomodulation for cancer therapy: providing treatment where needed," OncoImmunology, vol. 2, no. 11, Article ID e26493, 2013.

[16] G. Giemsa, "Eine Vereinfachung und Vervollkommnung meiner Methylenazur-Methylenblau-Eosin-Färbemethode zur Erzielung der Romanowsky-Nochtschen Chromatinfärbung," Centralbl. f. Bakt, vol. 37, pp. 308-331, 1904.

[17] A. B. Brown, Hematology: Principles and Procedures, Lea \& Febiger, Philadelphia, 6th edition, 1993.

[18] G. G. Luce, Biological Rhythms in Human and Animal Physiology, 1971, Paperback.

[19] A. Strecker, "Syntheses of aminoacids," Annalen der Chemie und Pharmacie, vol. 75, pp. 27-45, 1850.

[20] C. Pedregal, G. G. Trigo, M. Espada et al., "Utilisation des plans factoriels fractionnaires pour l'étude de la réaction de bucherer-bergs: Synthèse de la cyclohexane spirohydantoîne," Journal of Heterocyclic Chemistry, vol. 21, no. 5, pp. 1527-1531, 1984.

[21] V. K. Yu, "Stereochemistry of 1-(2-ethoxyethyl)-3-methyl-4,4disubstituted piperidines," Izv. MON RK, NAN RK. Ser.Khim, vol. 2, pp. 56-60, 2001. 
[22] V. K. Yu, "Esters of secondary alcohols of 1-alkoxyalkylpiperidines," Izv. MON RK, NAN RK. Ser.Khim, vol. 5, pp. 70-76, 2002.

[23] B. V. Unkovski, G. S. Gusakova, and I. A. Mokhir, "Esters of 1,3dimethyl- and 1,2,3-trimethyl-4-carbomethoxy-4-piperidols. The new analogues to $\alpha$-cocaine and $\alpha$-eukaine," Z.Obshch. Khim, vol. 30, pp. 3926-3931, 1960. 

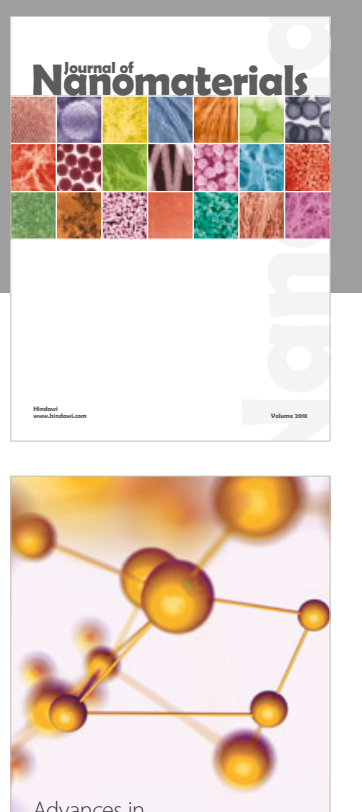

Physical Chemistry
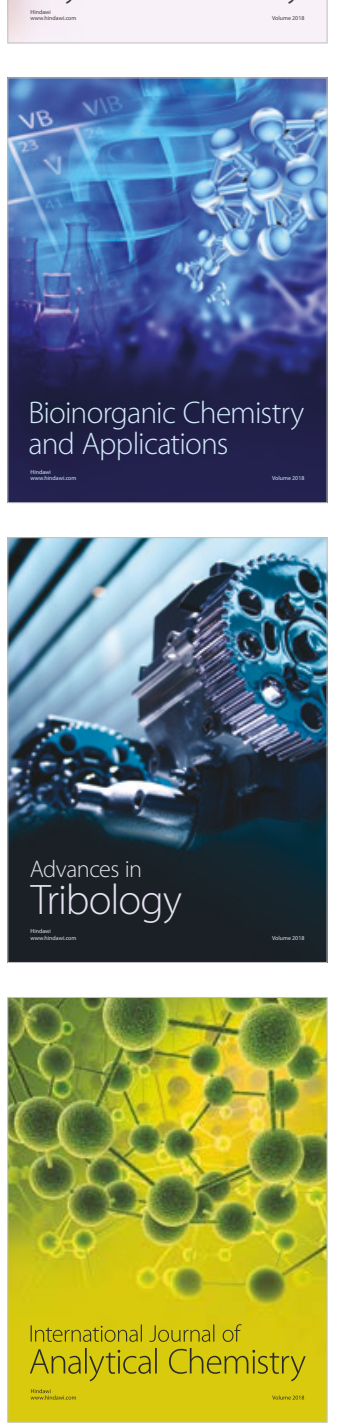

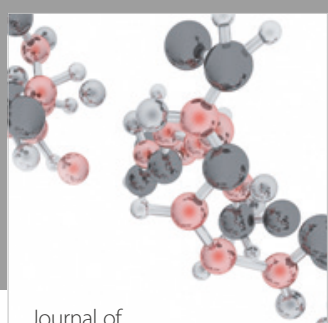

Analytical Methods

in Chemistry

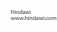

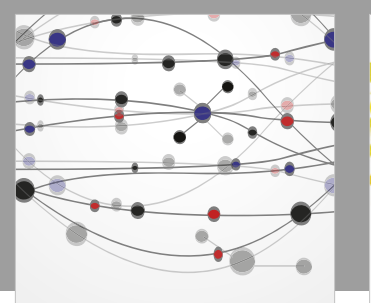

The Scientific World Journal

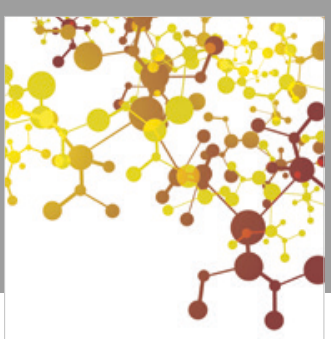

Journal of

Applied Chemistry
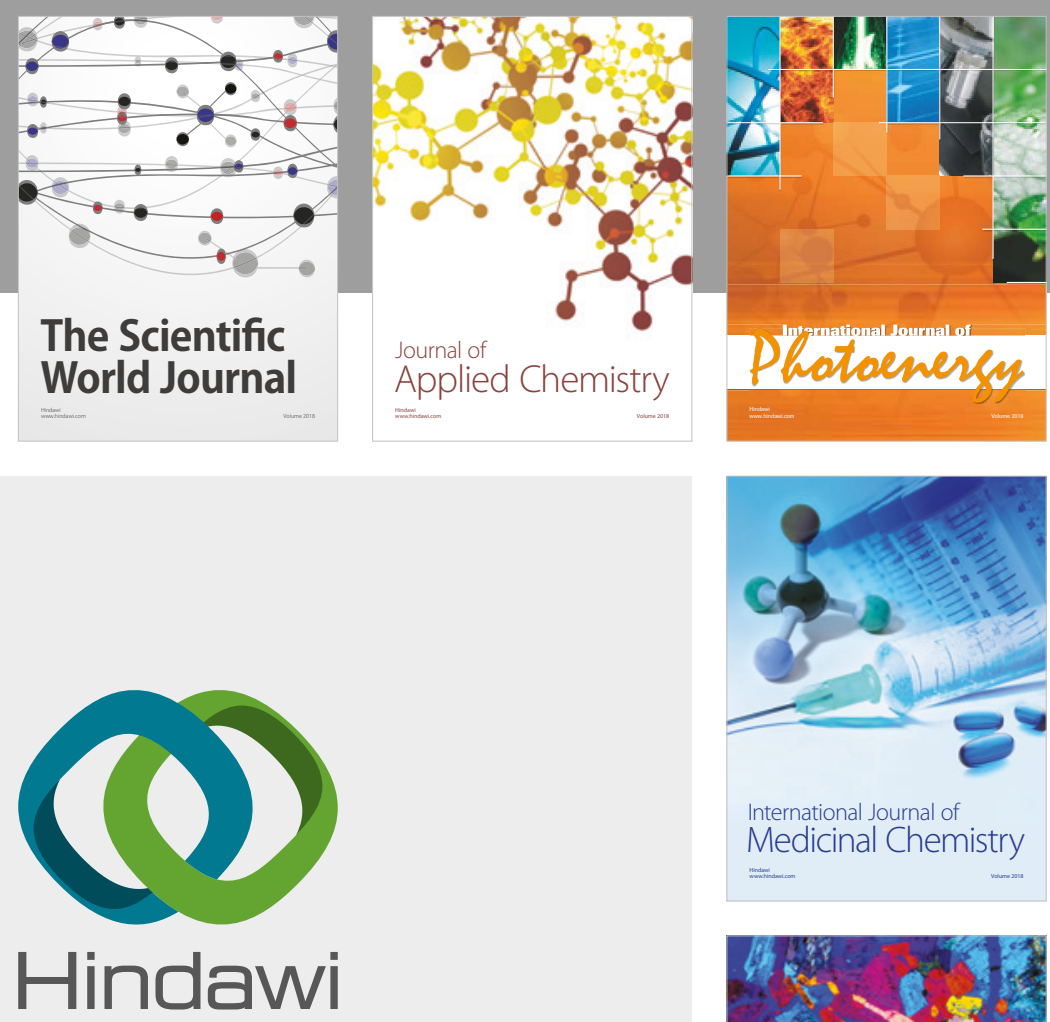

Submit your manuscripts at

www.hindawi.com
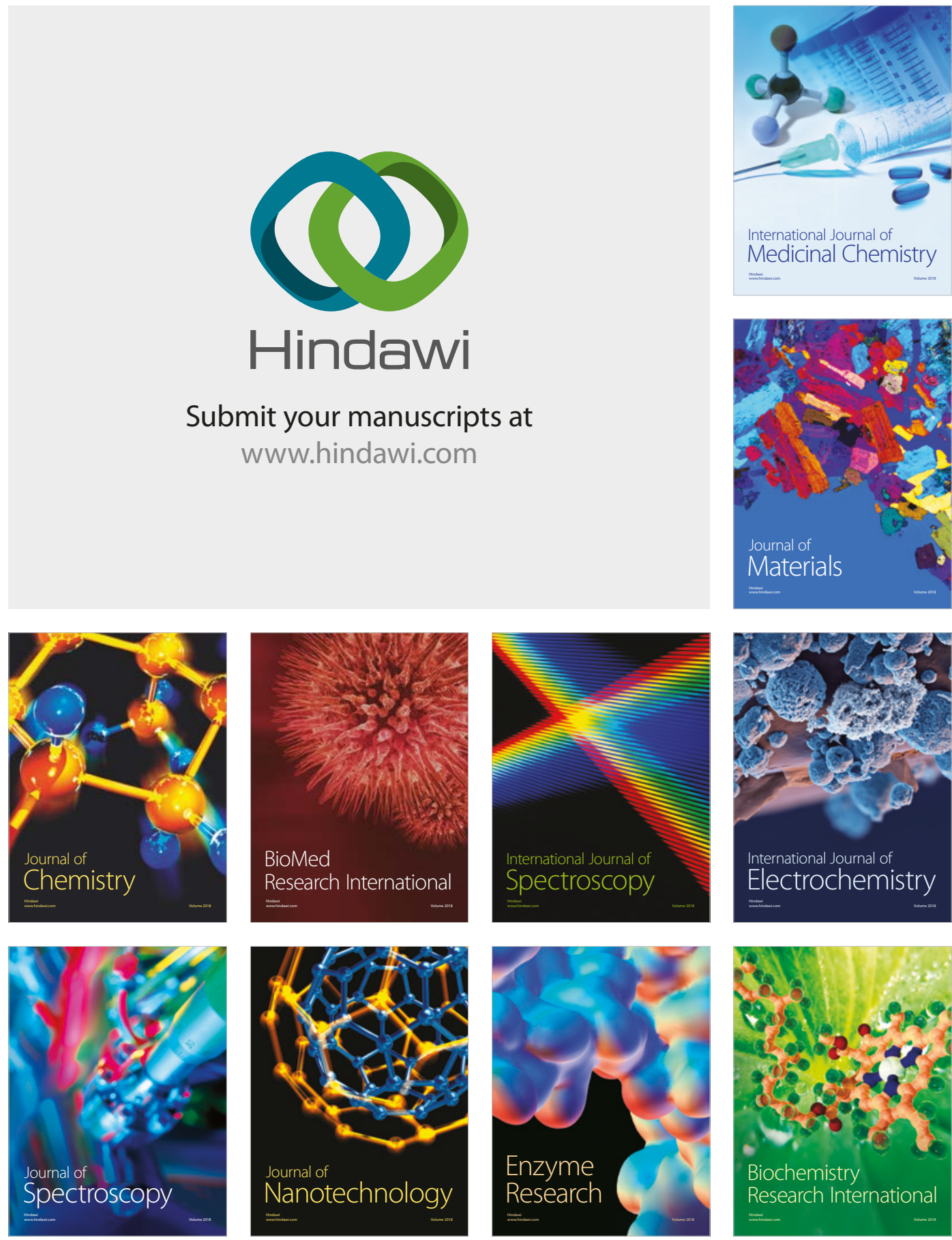
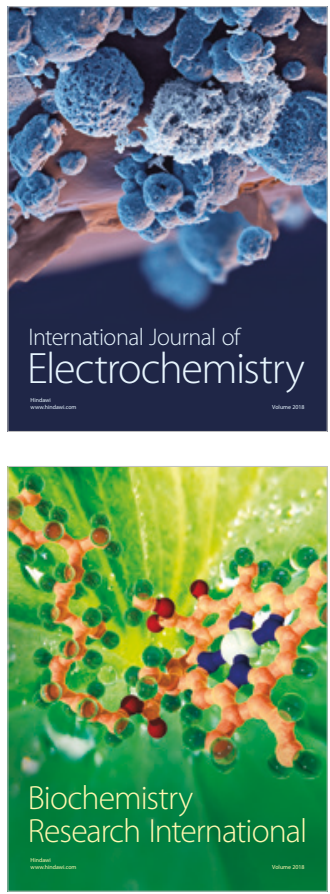